\title{
Study of Changes in Physical Parameters of compost and Vermicompost of Eucalyptus Leaf Litters
}

\author{
Ritu Nagar ${ }^{1 *}$, Anurag Titov ${ }^{1}$, Praveesh Bhati ${ }^{2}$ \\ ${ }^{1}$ Department of Botany, Madhav Science PG College, Ujjain (M.P.), India \\ ${ }^{2}$ DNA Finger Printing Unit, State Forensic Science Lab. Sagar, India
}

$\begin{aligned} & { }^{*} \text { Corresponding Author email: } \\ & \text { ritunagar021@gma }\end{aligned}$
Article History
Received: 10 March 2018
Revised: 23 March 2018
Accepted: 24 March 2018
Published: 04 April 2018
Student(s)
- Ritu Nagar
Academic Year: 2017-2018
Course Level: Master
Course Name: M.Sc. (Botany)
Course year: 2 ${ }^{\text {nd }}$ Year
Mentor(s)
• Anurag Titov
P Praveesh Bhati

* Corresponding Author email:

- $\quad$ Praveesh Bhati

\begin{abstract}
Vermicompost and compost of leaf litter of Eucalyptus was studied in plastic bins in duplicate sets with two different proportions (100\% and $50 \%$ ). For vermicompost experiments, epigeic earthworm species Eisenia foetida and Eudrilus engeniae were employed at 10-10 numbers each per vermicompost bins. Cattle dung was taken as control. During the entire process physical factors viz. temperature, $\mathrm{pH}$, moisture content and biomass were measured and compaired. The results were reveal that initial temperature was $35^{\circ} \mathrm{C} \pm 2^{\circ} \mathrm{C}$ in both vermicompost and compost leaf litter and after several weeks, it was set at minimum level. In $50 \%$ leaf litter temperature was $2-3^{\circ} \mathrm{C}$ higher than 100 $\%$ leaf litter. $\mathrm{pH}$ of both vermicompost and compost mixtures were acidic in beginning phase while set at alkaline at final stage. Vermicompost had lower $\mathrm{pH}$ than compost. Moisture content of leaf litter also decreased in initial phase due to generation of metabolic heat but at later phase it was increased due to decreasing of metabolic heat. More changed was seen in $100 \%$ leaf litter followed by $50 \%$ and then cattle dung. Biomass of leaf litter was more decreased in $100 \%$ waste then $50 \%$ and cattle dung.

Keywords : Eucalyptus leaf litter, vermicompost, compost, pH, temperature, moisture, biomass
\end{abstract}

\section{Introduction}

Using of fertilizer in agriculture is an imperative practice for accelerations of crops production. Bio-compost is one of the types of fertilizer using in agriculture. Bio-compost is prepared from cattle dung since long time by traditional manner. Although this technique is useful but prepare products limited with certain nutrients which do not fulfil the demand of agriculture resulting chemical fertilizer added as supplement. Presently it has been established that using of chemical fertilizer not only affect the natural quality of the soil but also cause bad effect on environment. Vermicomposting is an alternative way to prepare biofertilizer from similar waste using in compost preparation. Currently, vermicompost is preparing with the help of earthworm. Conventionally vermicompost generates from cattle dung as the substrate and has been recognized as a good soil conditioner and fertilizer [1]. In recent years along with cattle dung, other 
substrates are also vermicomposted and prepare products have been found to be as good as the cattle dung based vermicompost [2-6]. These results create idea to turn different types of organic waste such as municipal solid waste, crop wastes, weeds, leaf litter etc., into gainful vermicompost.

Eucalyptus is well known genus of flowering tree which is ubiquitous in nature. Although it is native to Australia, but some species also found in India. [7]. Eucalyptus globulus is common species, found in most of the part of India. There rapid growth, low nutritional requirement, higher tolerance nature to adverse condition and beastliness make it more attractive for plantation. Eucalyptus yields substantial quantities of leaf litter which is either broomed into the existing heaps of municipal solid waste (MSW), thereby adding to the MSW burden, or is made into piles and set on fire, thereby causing air pollution. Composting or vermicomposting of leaf litters with cattle dung is better option to turn waste into best. It will not only decrease the pollution but also increase the availability of plant nutrients.

During composting and vermicomposting of Eucalyptus leaf litters, physical factors like $\mathrm{pH}$, temperature, moisture content, biomass reduction, odour etc. are also significantly changed. Similar work was also done by several scientists by using different types of organic waste. Shouche et al. [8] worked on floral waste vermicomposting and revealed that different physical parameters varied periodically and became stable at the end of the process. They were also found $60-70 \%$ moisture percent and $25-30^{\circ} \mathrm{C}$ temperature for proper activity of microorganisms and earthworms. Larney and Blackshow [9] was stated that in Initial phase of composting or vermicomposting moisture content was decreased due to high evaporating rates at high thermophilic phase. Liang et al [10] also observed that at the end of process, moisture percentage increase due to the production of high absorption capacity of vermicompost. Peigne and Girardin [11] also revealed that during composting process, temperature increase initially but when process drive to last stage then temperature turn decrease. During composting and vermicomposting, $\mathrm{pH}$ also changed significantly. Singh et al [12] found that during vermicomposting of rose flowers $\mathrm{pH}$ has changed from 4.3 to 8.2. Vogt et. al. [13] was reported about reduction in biomass during decomposition process due to loss of water by heat. It has also reported that about $40 \%$ volume of waste materials reduced from their parent mass in composting process. [14]. Ndegwa and Thompson [15] also suggested that during the process of composting and vermicomposting, bio solid waste reduced approximately $45 \%$ by their original weight.

The present study was done to change and compair the vicissitudes in physical factors during composting and vermicomposting of Eucalyptus leaf litter. For vermicomposting, two species of earthworm i.e. Eisenia foetida and Eudrilus engenia were taken which are known to be voracious feeders and have other attributes suitable for vermicomposting.

\section{Material and Methods}

\subsection{Collection of Plant Leaves and Cattle Dung}

In present experiment cattle dung was collected according to the method of Shouche et..al. [8] and was brought to vermicomposting unit, Govt. Madhav Science College Ujjain. Eudrilus engeniae and Eisenia foetida equally used in this study were obtained from vermiculture centre of Govt. Madhav Science College, Ujjain (M.P.) [16, 17]. The leaf litter of Eucalyptus (Eucalyptus globulus) used as a substrate was collected at random from the College campus of Govt. Madhav Science P.G. College, Ujjain (M.P).

\subsection{Preparation for Vermicomposting}

Collected leaf wastes was chopped into small pieces and mixed with cattle dung in equal volume. $100 \%$ cattle dung and leaf litter were taken as a control for study.

\subsection{Process of Vermicomposting and Composting}

Both composting and vermicomposting process carried out in plastic containers in duplicate manner. During the process all containers kept openly in room which was aerated passively i.e. no any effort was done for supply of air. Waste materials were turned after regular interval of time for dissipate heat as well as enhances passive aeration [18]. In order to fulfil moisture loss, mixtures were sprinkled with water after 
Ngar et al., Adv.J. Grad. Res.; Vol. 4, Issue 1, pp: 34-40, July 2018

turning it upside down. In case of vermicomposting sets, leaf litter-cattle dung mixtures were predecomposed for fifteen days prior adding of earthworms while other sets for composting, were run continuously without earthworm. Twenty earthworms (E. engeniae and E. foetida) were added in vermicomposting bins [12].

\subsection{Measurement of Physical Parameters}

During vermicomposting and composting of Eucalyptus leaf litters, physical variables viz. $\mathrm{pH}$, temperature biomass and moisture were measured change according to the methods carried out by different researchers $[8,19,20,21]$. $\mathrm{pH}$ was measured by digital $\mathrm{pH}$ meter (Systonic) in which electrode was immersed in beaker containing vermicompost or compost suspension (figure 1). A moisture change was recorded by drying of composting materials $(5.0 \mathrm{gm})$ in hot air oven at $105^{\circ} \mathrm{C}$ for $24 \mathrm{hrs}$. and taken dry weight by electronic balance (Citizon) (figure 2). Biomass reduction was measured with the help of scale at all four side marked areas and their mean value was taken (figure 3). In case of temperature measurement, mercury thermometer was inserted into composting bins at three different places in different depth and their mean value was record (figure 4).

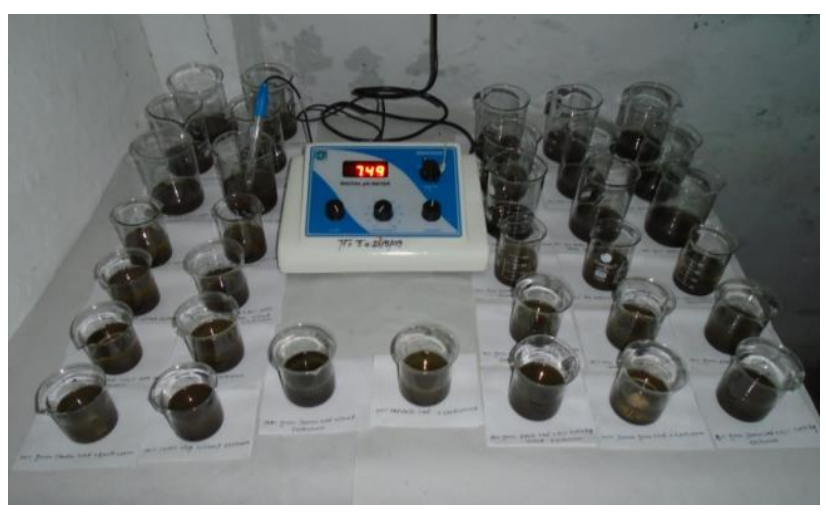

Figure1: Measurement of $\mathrm{pH}$ using digital $\mathrm{pH}$ meter.

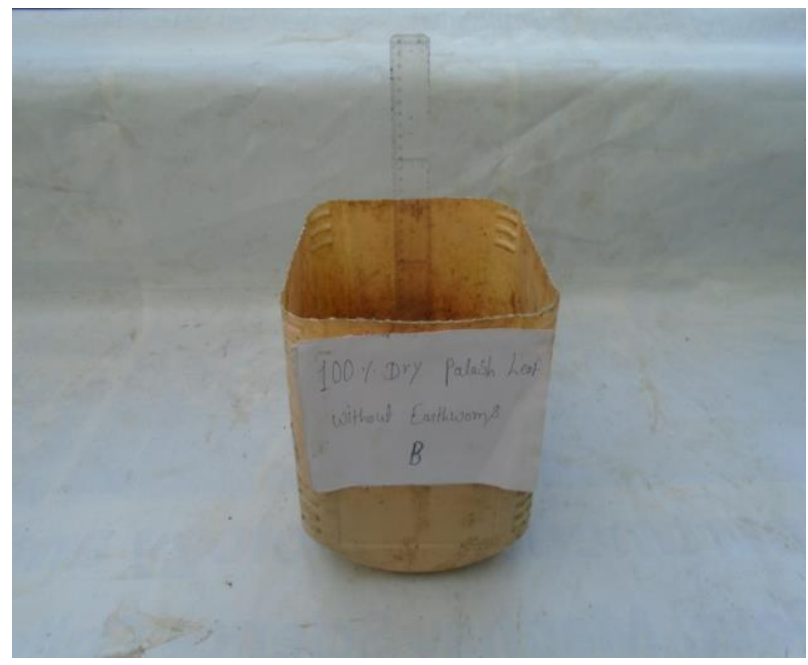

Figure 3: Measurement of depth of vermicomposting and composting mixture.

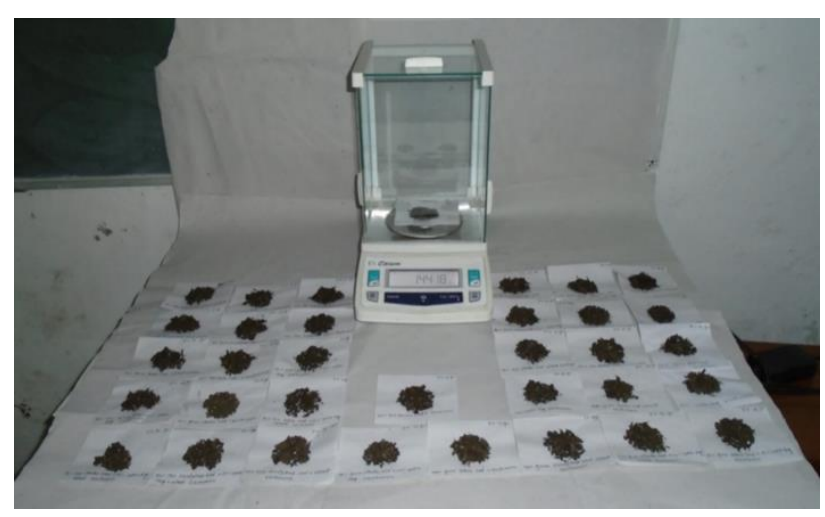

Figure 2: Measurement of moisture of vermicomposting and composting mixtures

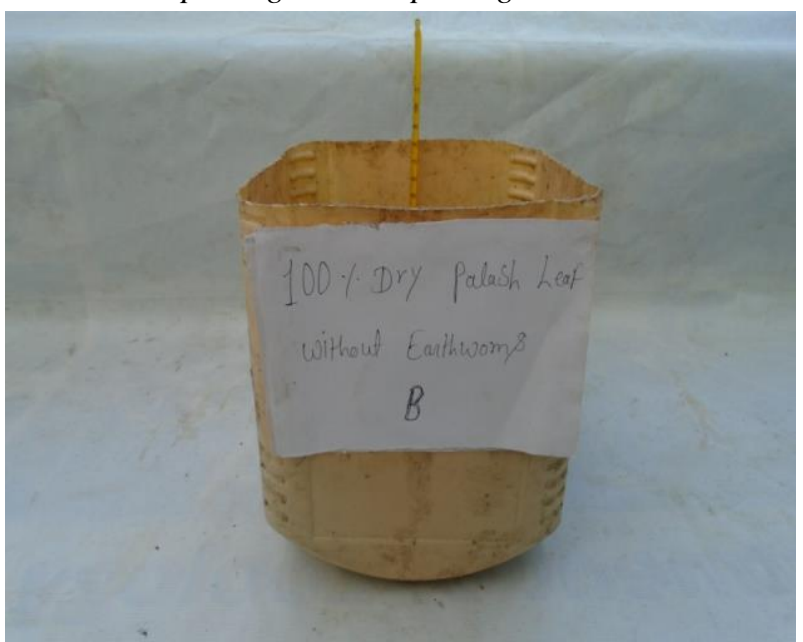

Figure 4: Measurement of temperature of vermicomposting and composting mixture.

\section{Results and Discussion}

Decomposition of organic wastes is a biological process in which physical factor of waste get change during the course of process time duration and set at constant point at the end of phase. In present work, leaf litters of Eucalyptus were subjected to vermicompost and compost with and without cattle dung and evaluate different physical parameters comparatively. Parameters viz. moisture content, depth, $\mathrm{pH}$ and temperature were measured for both $100 \%$ leaf litter and 50: 50 of leaf litter-cattle dung mixture of 
vermicompost and compost sets. The table 1 is given to all physical parameters related to the treatment of earthworm (vermicompost) with a mixture of leaf and cattle dung while all parameters related to mixture of leaf litters and cattle dung without treatment of earthworm (compost) are given in table 2. The control parameters of both vermicompost and compost of cattle dung are depicted in table 3. During measurement of moisture, it was notice that initial moisture level of $100 \%$ leaf litter was $68 \pm 1 \%$ while in $50 \%$ Eucalyptuscattle dung mixture, it was $65 \pm 1 \%$ in compaired to cattle dung $(60 \%)$ using as a control. At the end of process (after 13 weeks) it was recorded $81 \pm 1 \%$ in $100 \%$ leaf litter while $75 \pm 1 \%$ in $50 \%$ Eucalyptuscattle dung mixture of both vermicomposting and composting sets while in control it was $66 \pm 1 \%$. Result revealed that moisture level was changed $13 \pm 1 \%$ in $100 \%$ leaf litter while $10 \pm 1 \%$ in $50 \%$ mixtures in both composting and vermicomposting sets as compaired to $6 \pm 1 \%$ in cattle dung.

Table 1: Variation in different physical parameters of leaf litters and cattle dung mixture treated by earthworms.

\begin{tabular}{|c|c|c|c|c|c|c|c|c|}
\hline \multirow{3}{*}{$\begin{array}{l}\text { No. of } \\
\text { Week }\end{array}$} & \multicolumn{8}{|c|}{ Earthworm (Vermicomposting) } \\
\hline & \multicolumn{2}{|c|}{ Moisture percentage } & \multicolumn{2}{|c|}{$\begin{array}{c}\text { Depth of biomass } \\
(\mathbf{c m})\end{array}$} & \multicolumn{2}{|c|}{ pH } & \multicolumn{2}{|c|}{ Temperature $\left({ }^{\circ} \mathbf{C}\right)$} \\
\hline & $100 \%$ & $50 \%$ & $100 \%$ & $50 \%$ & $100 \%$ & $\mathbf{5 0} \%$ & $100 \%$ & $50 \%$ \\
\hline $1^{\text {st }}$ & 67.62 & 64.33 & 28.90 & 26.42 & 5.5 & 5.6 & 33.7 & 36.3 \\
\hline $2^{\text {nd }}$ & 69.36 & 64.45 & 25.39 & 23.45 & 6.2 & 6.4 & 32.6 & 34.4 \\
\hline $3^{\text {rd }}$ & 70.28 & 65.45 & 23.86 & 21.23 & 6.5 & 6.7 & 30.6 & 32.5 \\
\hline $4^{\text {th }}$ & 72.53 & 66.69 & 20.42 & 19.84 & 6.7 & 6.9 & 28.7 & 29.8 \\
\hline $5^{\text {th }}$ & 74.29 & 67.79 & 18.77 & 17.38 & 6.9 & 7.2 & 27.5 & 28.8 \\
\hline $6^{\text {th }}$ & 75.58 & 68.83 & 16.57 & 15.83 & 7.2 & 7.3 & 26.7 & 26.9 \\
\hline $7^{\text {th }}$ & 75.43 & 70.52 & 14.42 & 14.89 & 7.3 & 7.4 & 24.9 & 25.7 \\
\hline $8^{\text {th }}$ & 77.75 & 71.19 & 13.83 & 13.95 & 7.5 & 7.5 & 21.9 & 24.56 \\
\hline $9^{\text {th }}$ & 78.92 & 72.78 & 11.59 & 12.25 & 7.6 & 7.7 & 21.6 & 22.9 \\
\hline $10^{\text {th }}$ & 79.35 & 73.32 & 10.90 & 10.52 & 7.7 & 7.8 & 20.8 & 21.7 \\
\hline $11^{\text {th }}$ & 80.65 & 74.35 & 9.37 & 9.58 & 7.8 & 7.9 & 20.3 & 21.6 \\
\hline $12^{\text {th }}$ & 80.89 & 75.49 & 9.22 & 9.12 & 7.9 & 8.00 & 19.6 & 20.6 \\
\hline $13^{\text {th }}$ & 81.35 & 75.39 & 8.65 & 8.10 & 8.00 & 8.1 & 18.8 & 19.7 \\
\hline
\end{tabular}

Table 2: Variation in different physical parameters of leaf litters and cattle dung mixture without earthworm treatment.

\begin{tabular}{|c|c|c|c|c|c|c|c|c|}
\hline \multirow{3}{*}{$\begin{array}{l}\text { No. of } \\
\text { Week }\end{array}$} & \multicolumn{8}{|c|}{ Without Earthworm (composting) } \\
\hline & \multicolumn{2}{|c|}{$\begin{array}{c}\text { Moisture } \\
\text { percentage }\end{array}$} & \multicolumn{2}{|c|}{$\begin{array}{c}\begin{array}{c}\text { Depth of biomass } \\
(\mathrm{cm})\end{array} \\
\end{array}$} & \multicolumn{2}{|c|}{ pH } & \multicolumn{2}{|c|}{$\begin{array}{c}\text { Temperature } \\
\left({ }^{\circ} \mathrm{C}\right)\end{array}$} \\
\hline & $100 \%$ & $50 \%$ & $100 \%$ & $50 \%$ & $100 \%$ & $50 \%$ & $100 \%$ & $50 \%$ \\
\hline $1^{\text {st }}$ & 69.28 & 66.29 & 29.59 & 27.16 & 5.6 & 5.7 & 33.5 & 35.5 \\
\hline $2^{\text {nd }}$ & 70.74 & 67.32 & 26.42 & 24.27 & 6.2 & 6.3 & 32.8 & 34.7 \\
\hline $3^{\text {rd }}$ & 71.95 & 68.66 & 24.15 & 22.29 & 6.4 & 6.6 & 30.5 & 33.6 \\
\hline $4^{\text {th }}$ & 72.24 & 69.54 & 21.17 & 19.38 & 7.2 & 7.4 & 27.4 & 31.2 \\
\hline $5^{\text {th }}$ & 73.21 & 70.25 & 19.45 & 17.29 & 7.4 & 7.6 & 26.4 & 28.9 \\
\hline $6^{\text {th }}$ & 75.46 & 71.23 & 18.33 & 16.65 & 7.5 & 7.7 & 24.5 & 27.5 \\
\hline $7^{\text {th }}$ & 77.44 & 72.45 & 16.69 & 15.58 & 7.6 & 7.8 & 23.3 & 26.5 \\
\hline $8^{\text {th }}$ & 78.29 & 73.37 & 13.58 & 13.24 & 7.7 & 7.9 & 22.6 & 24.4 \\
\hline $9^{\text {th }}$ & 79.39 & 74.24 & 12.63 & 12.64 & 7.9 & 8.00 & 21.2 & 23.4 \\
\hline $10^{\text {th }}$ & 79.83 & 74.89 & 11.17 & 10.56 & 7.9 & 8.1 & 20.5 & 21.5 \\
\hline $11^{\text {th }}$ & 80.11 & 75.03 & 9.52 & 9.94 & 8.00 & 8.2 & 19.8 & 21.2 \\
\hline $12^{\text {th }}$ & 80.37 & 75.83 & 8.99 & 9.58 & 8.1 & 8.2 & 19.5 & 20.4 \\
\hline $13^{\text {th }}$ & 81.32 & 76.64 & 8.80 & 8.39 & 8.1 & 8.3 & 18.7 & 19.6 \\
\hline
\end{tabular}


Ngar et al., Adv.J. Grad. Res.; Vol. 4, Issue 1, pp: 34-40, July 2018

Table 3: Variation in different physical parameters of cattle dung with and without treatment of earthworms.

\begin{tabular}{|c|c|c|c|c|c|c|c|c|}
\hline \multirow{2}{*}{$\begin{array}{c}\text { No. of } \\
\text { Week }\end{array}$} & \multicolumn{9}{|c|}{ Cattle dung } \\
\cline { 2 - 9 } & \multicolumn{2}{|c|}{\begin{tabular}{c} 
Moisture percentage \\
\hline $1^{\text {st }}$
\end{tabular}} & \multicolumn{2}{|c|}{$\begin{array}{c}\text { Depth of biomass } \\
(\mathbf{c m})\end{array}$} & \multicolumn{2}{|c|}{$\mathbf{p H}$} & \multicolumn{2}{c|}{ Temperature $\left({ }^{\circ} \mathbf{C}\right)$} \\
\hline $2^{\text {nd }}$ & 60.35 & 60.35 & 14.84 & 14.84 & 8.5 & 8.5 & 38.5 & 38.5 \\
\hline $3^{\text {rd }}$ & 61.37 & 61.37 & 12.78 & 12.78 & 8.4 & 8.4 & 35.4 & 35.4 \\
\hline $4^{\text {th }}$ & 62.95 & 62.95 & 11.11 & 11.11 & 8.3 & 8.3 & 33.8 & 33.8 \\
\hline $5^{\text {th }}$ & 63.83 & 63.83 & 10.68 & 10.68 & 8.2 & 8.2 & 32.5 & 32.5 \\
\hline $6^{\text {th }}$ & 64.69 & 64.69 & 10.34 & 10.34 & 8.2 & 8.2 & 29.9 & 29.9 \\
\hline $7^{\text {th }}$ & 64.89 & 64.89 & 9.72 & 9.72 & 8.1 & 8.1 & 27.5 & 27.5 \\
\hline $8^{\text {th }}$ & 65.65 & 65.65 & 8.74 & 8.74 & 8.1 & 8.1 & 25.5 & 25.5 \\
\hline $9^{\text {th }}$ & 66.28 & 66.28 & 7.95 & 7.95 & 8.00 & 8.00 & 24.7 & 24.7 \\
\hline $10^{\text {th }}$ & 66.35 & 66.35 & 6.17 & 6.17 & 8.00 & 8.00 & 22.9 & 22.9 \\
\hline
\end{tabular}

Note: $\mathrm{V}=$ vermicompost (earthworm treated), $\mathrm{C}=$ compost (without earthworm), $\mathrm{cm}=$ centimetre

During the entire experiment water was added in all composting bins after regular interval of time so that lost water fulfils by addition of supply water. Moisture loss may be due to metabolic heat, generated by microbial community found in composting bins as well as inter-cellular digestion in the gut of earthworm. It has been also found that existence of abundant quantity of organic waste labile for great metabolic activity, result generating of much heat and this rate is directly proportional to the moisture loss. As the degradation rate of waste increases, then its availability decrease, resulting heat generation rate gradually decrease $[22,23,24]$. In our experiment, ample vapour loss was seen in initial phase of composting process but at the end of composting phase, moisture loss decreased due to low heat generation because of consumption of almost organic matters. In case of cattle dung, organic waste were almost digested in ruminant stomach therefore due to less availability of organic compound, less heat generates thus the water loss also minimum as compaired to $100 \%$ and $50 \%$ leaf litters. Our result was concordance with result of solid waste and food waste composting done by Suler-Finstein and Sundberg [25, 26].

During the work, depth of composting and vermicomposting mixtures was also measured. It was found that initial height of leaf litter biomass was $27 \pm 1 \mathrm{~cm}$ in both $100 \%$ and $50 \%$ and $14 \pm 1 \mathrm{~cm}$ was in cattle dung in both vermicompost and compost bins when the experiment started. The height gradually decreased during the decomposition and finally it was set at the height of $8.0 \pm 1 \mathrm{~cm}$. in leaf litter while $6.0 \pm 1 \mathrm{~cm}$ in cattle dung in both vermicompost and compost sets. Based on the result obtain it was found that during decomposition process, about $70 \%$ height in leaf litter waste and $57 \%$ height cattle dung were reduced. Similar result obtained by Chaudhuri et.al. when he did the vermicomposting of kitchen waste [27]. Biomass of organic waste consists of water as well as biopolymers viz. carbohydrate, protein etc. along with water which make them bulky. During the composting, microorganisms and earthworm (in case of vermicompost) digest complex material into simplest form, resulting generation of heat and gas. Such heat transforms water into vapour. Therefore, digestion of organic waste and its water loss in the form of vapour are main causes for diminish the height of biomass $[28,29]$. It was also found that depth reduction rate in vermicompost set was higher than compost set in both $100 \%$ and $50 \%$ leaf litters as well as in control (cattle dung) was also supported by result of Singh et.al [30] who worked on decomposition kitchen waste. $\mathrm{pH}$ was also measured and compared during decomposition process. It was found that initial $\mathrm{pH}$ of leaf litter waste was $5.6 \pm 0.2$ in both vermicompost and compost sets while the $\mathrm{pH}$ of control (cattle dung) was $8.5 \pm 0.2$. As decomposition of leaf litters waste progress, $\mathrm{pH}$ was increased gradually and finally set near alkaline. Shouche et.al also found same result while working on floral waste vermicomposting. When Sannigrah worked on leaf litter degradation then he also found neutral to alkaline $\mathrm{pH}$ of vermicompost while more alkaline $\mathrm{pH}$ in prepared compost $[8,31]$. The $\mathrm{pH}$ of any organic compound depends upon their chemical constituents. When the process of composting begins, the present microorganism takes carbohydrate preferentially and form $\mathrm{CO}_{2}$ and water after metabolism. When generate $\mathrm{CO}_{2}$ dissolved in 
water then $\mathrm{pH}$ of medium turn into acidic. In our experiment, initial $\mathrm{pH}$ of leaf waste in both vermicompost and compost was also found acidic. When there is constant use of carbohydrate, then its quantity gradually decreases then microorganism begin to metabolized another compound for getting energy i.e. protein. Because protein is a nitrogenous compound which gives rise to ammonia at the end of metabolism causes alkaline condition in medium [27, 32]. Our result also found alkaline $\mathrm{pH}$ at the end of composting and vermicomposting process.

Temperature was also measured during the decomposition process. It was higher at beginning phase but gradually decreased and set at lower point alike to room temperature. In the beginning of the process, i.e, up to 21 days, the temperature was high $\left(32\right.$ to $\left.33^{\circ} \mathrm{C}\right)$ in both vermicompost and compost bins in comparison to room temperature $\left(26\right.$ to $\left.30^{\circ} \mathrm{C}\right)$. Later, there was a gradual fall in temperature that reached at minimum level was $18^{\circ} \mathrm{C}$ (close to room temperature). However, higher temperature was recorded in vermicompost than compost bins during the entire period of decomposition process. It was also found that temperature was higher in $50 \%$ of leaf litter-cattle dung mixture than $100 \%$ leaf litter waste. It was also explore that there were $14-18^{\circ} \mathrm{C}$ difference between initial and final temperature of vermicompost and compost leaf litter waste while in case of control it was about $16^{\circ} \mathrm{C} \pm 1{ }^{\circ} \mathrm{C}$.It has been found that initial temperature raised as a result of biochemical processes and decomposition of organic components of waste. As soon as organic waste depleted the temperature also turn down and set at lower constant value [23].

\section{Conclusion}

Vermicomposting and composting are more or less similar but distinct technique to exploit bio organic waste as a fertilizer for betterment and increase soil fertility. Both techniques undergo several physical, chemical and biological changes to established finished product. Present study revelled about fluctuations in different physical parameters viz. moisture concentration, as well their comparative account regarding the vermicomposting and composting of Eucalyptus leaf litter-cattle dung mixture. Moisture loss is more frequently in those sets $(50 \%)$ which contain more cattle dung as well as presence of earthworms (vermicompost). It has also clear that these sets having also comparatively high temperature due to more biochemical activities. Result also explores that in such sets biomass also reduced more prominently. It has also found that $\mathrm{pH}$ of all sets either vermicompost or compost, turn to alkaline. Present finding can apply for the study of effect of different substrate on the growth of earthworm and also finest state at which earthworm can abide physical conditions for growth. Although this study done with cattle dung which considered as a good food source for earthworm but using of different animal dung may change the survival rate of earthworm which may be key factors for preparing vermicompost. With consideration the result of present study, earthworm should be applied when favorable condition sets in composting bins.

\section{Acknowledgment}

We are thankful to Principal, Govt. Madhav Science College for providing permission for conducting vermicomposting of leaf waste. The authors also wish to express their warm gratitude to the Department of Botany, Biotechnology \& Microbiology for accompanying laboratory experiment.

\section{How to Cite this Article:}

R. Nagar, A. Titov, and P. Bhati, "Study of Changes in Physical Parameters of compost and vermicompost of Eucalyptus leaf litters", Advanced Journal of Graduate Research, vol. 4, no. 1, pp. 34-40, Apr. 2018. doi: 10.21467/ajgr.4.1.34-40

\section{References}

[1] S A. Ismail, "Vermitechnology: The Biology of Earthworms", Orient Longman, Chennai, India.1997.

[2] S. Gajalakshmi and S A. Abbasi, "Neem leaves as a source of fertilizer-cum pesticide vermicompost", Bio resource Technology, vol.92, pp.291-296, 2004.

[3] S. Gajalakshmi and S A. Abbasi,, "Vermiconversion of paper waste by earthworm born and grown in the waste-fed reactors compared to the pioneers raised to adulthood on cowdung feed" Bioresource Technology, vol. 94,pp.53-56, 2004.

[4] S. Gajalakshmi, E V. Ramasamy and S A. Abbasi, "High-rate composting-vermicomposting of water hyacinth (Eichhornia crassipes, Mart Solms)", Bioresource Technology, vol.83, pp.235-239, 2002. 
[5] S. Gajalakshmi, P.Sankar Ganesh, and S A. Abbasi, "A highly cost-effective simplification in the design of fast-paced vermireactors based on epigeic earthworms", Biochemical Engineering Journal, vol.22,pp.111-116, 2005.

[6] S.Gajalakshmi, E. V. Ramasamy and S. A. Abbasi, "Composting-vermicomposting of leaf litter ensuing from the trees of mango (Mangifera indica)", Bioresource Technology, vol. 96,pp. 1057-1061, 2005.

[7] T. Takahashi, R. Kokubo and M. Sakainom, "Antimicrobial activities of Eucalyptus leaf extracts and flavonoids from Eucalyptus maculate", Letters in Applied Microbiology, vol.39, pp.60-64, 2004.

[8] S. Shouche, P. Bhati and P. Pandey, "Study about the changes in physical parameters during vermicomposting of floral wastes" Journal of Environmental Research and Development, vol.6, no.1, pp.63-68, 2011.

[9] F J. Larney and R. E. Blackshaw, "Weed seed viability in composted beef cattle feedlot manure", J. Environ. Qual, vol. 32,pp.1105$1113,2003$.

[10] C. Liang, K. C. Das and R. W. McClendon "The influence of temperature and moisture contents regimes on the aerobic microbial activity of a biosolids composting blend" Bioresource Technology, vol.86, no.2, pp.131-137, 2003.

[11] J. Peigne and P. Girardin, "Environmental impacts of farm-scale composting practices", Water Air Soil Pollut, vol.153, pp. 45-68, 2004.

[12] N. B. Singh, A. K. Khare, D. Bhargava and S. Bhattacharya, "Effect of initial substrate ph on vermicomposting using Perionyx excavatus (perrier, 1872)" Applied ecology and environmental research, vol.4, no.1, pp. 85-97, 2005.

[13] K. A. Vogt, C. C. Grier and D. J. Vogt, "Production, turnover, and nutrient dynamics of above- and below ground detritus of world forests", Adv. Ecol. Res, vol.15, pp.303-377, 1986.

[14] J. R. Banu I.T. Yeom, S. Esakkiraj, N. Kumar and S. Logakanthi, "Bio management of sago-sludge using an earthworm, Eudrilus eugeniae". Journal of Environmental Biology, vol.29, no.2, pp.143-146, 2008.

[15] P M. Ndegwa, and Thompson S. A. 2001.Integrating composting and vermicomposting in the treatment and bioconversion of biosolids. Bioresource Technology .76:107-112.

[16] R. Nagar, A. Titov and P. Bhati, "Vermicomposting of green Eucalyptus leaf litter by Eisenia foetida and Eudrilus eugenia", International Journal of Environment, Agriculture and Biotechnology (IJEAB), vol.2, no.6, pp.2811-2818,2017.

[17] R. Nagar, A. Titov and P. Bhati, "Vermicomposting of Leaf litters: Way to convert waste in to Best", INT J CURR SCI, vol.20, no.4, pp. E 17-25, 2017.

[18] NRAES.1992. On-farm composting (Ed. Rynk, Robert). Natural Resource, Agriculture, and Engineering Service, Cooperative Extension, Ithaka, New York.

[19] H. Alidadi, A. R. Paravaresh, M.R. Shahmansouri and P. Pourmoghadas, "Combined compost and vermicomposting process in the treatment and bioconversion of sludge" Iran J. Environ. Health. Sci. Eng. vol.2, no.4, pp. 251-254, 2005.

[20] P M. Munnoli and S. Bhosle, "Effect of soil and cow dung proportion on vermin-composting by deep burrower and surface feeder species", Journal of Scientific and Industrial Research,vol.68,pp.57-60, 2009.

[21] N A.Fairey, "An evaluation of five methods for the determination of moisture in grass seeds", Canadian Journal of Plant Science,vol.81,no.3,pp.401-405, 2002.

[22] S.J. Pirt, "Aerobic and anaerobic Microbial digestion in waste reclamation”, J Appl. Chemistry and Biotechnology. 28: 232-236, 1978.

[23] X. Lefebvre, S.Lanini and D. Houi "The role of aerobic activity on refuse temperature rise :I. Land fill experimental study," Waste Manage .Res,vol.18,no.5,pp. 444-452, 2000.

[24] H. Yoshida and R. K. Rowe,"Consideration Of landfill liner temperature."Proc., Sardinia, $9^{\text {th }}$ Int. Waste Management and Landfill Symp., T.H. Christensen, R.Cossu and R. Stegmann, eds.,CISA, Italy, 2003.

[25] D.J. Suler and M.S. Finstein, "Effect of temperature, aeration, and moisture on $\mathrm{CO}_{2}$ formation in bench-scale, continuously thermophilic composting of solid waste" Appl. Environ. Microbiol . vol.33, no.2, pp.345-350,1977.

[26] C. Sundberg "Food waste composting - effects of heat, acids and size", Ph.D. Dissertation, Swedish University of Agricultural Sciences, 2003.

[27] P. S. Chaudhuri, T. K. Pal, G.Bhattacharjee and S.K. Dey, “Chemical changes during vermicomposting (Perionyx excavatus) of kitchen wastes, Tropical Ecology. Vol.41,no.1,pp.107-110, 2000.

[28] K. E. Lee, "Earthworms. Their Ecology and Rela-tionships with Soils and Land Use", Academic Press, Sydney, 1985.

[29] M. Ghosh, G.N. Chattopadhyay and K. Baral, "Transformation of phosphorus during vermicom-posting", Bioresource Technology, vol. 69,pp.149-154,1999.

[30] G. S. Singh, A.M. Jana and A. Shrivastava, "A review on "Anaerobic bacterial degradation of kitchen waste". Int. J. Res. Dev. Pharm. L. Sci, vol.3, no.2, pp.850-854, 2014.

[31] J.Dominguez, A.Clive and C.A. Edwards, "Vermicomposting organic wastes: A Review Soil Zoology for Sustainable Development in the 21 st Century" ,S.H. Shakir Hanna and W.Z.A. MikhaTl, eds, Cairo,2004.

[32] A.K. Sannigrah, "Biodegradation of leaf litter of tree species in presence of cow dung and earthworms" Indian Journal of Biotechnology.vol.8, pp. 335-338, 2009.

Publish your research article in AIJR journals-

- Online Submission and Tracking

- Peer-Reviewed

- Rapid decision

- Immediate Publication after acceptance

- Articles freely available online

- Retain full copyright of your article.

Submit your article at journals.aijr.in
Publish your books with AIJR publisher-

- Publish with ISBN and DOI.

- Publish Thesis/Dissertation as Monograph.

- Publish Book Monograph.

- Publish Edited Volume/ Book.

- Publish Conference Proceedings

- Retain full copyright of your books.

Submit your manuscript at books.aijr.org 